\title{
A POLÍTICA CULTURAL NA REVOLUÇÃO CUBANA: as disputas intelectuais nos anos 1960 e 1970
}

\author{
Sílvia Cezar Miskulin*
}

\begin{abstract}
A Revolução Cubana promoveu grandes transformações na sociedade da ilha. Novas publicações, instituições culturais e manifestações artísticas acompanharam a efervescência política e cultural ao longo dos anos 60. Esta pesquisa analisou o suplemento cultural Lunes de Revolución, a editora El Puente e o suplemento cultural El Caimán Barbudo, com o objetivo de mostrar o surgimento das novas publicações e manifestações culturais em Cuba após o triunfo da Revolução. O trabalho demonstra que o surgimento de uma política cultural acarretou a normatização e o controle das produções culturais pelo governo cubano desde os anos 1960, e mais ainda após 1971, quando se acentuou o fechamento e o endurecimento no meio cultural cubano.
\end{abstract}

Palavras-Chave: Cuba. Revolução. Cultura. História. Intelectual.

\section{INTRODUÇÃO}

Com o triunfo da Revolução em 1959, desenvolveu-se, em Cuba, uma intensa movimentação cultural, marcada pelo surgimento de novas publicações, instituições, editoras, teatros e inúmeras manifestações artísticas e musicais. Novas oportunidades de trabalho e incentivos à criação foram fundamentais para o florescimento do meio intelectual e cultural cubano. Neste mesmo ano, nasceram importantes marcos na cultura cubana: Icaic, Casa de las Américas, e Lunes de Revolución. O surgimento do Icaic, Instituto Cubano del Arte y Industria Cinematográficas, em 24 de março de 1959, mostrou a importância de fomentar e organizar a produção cinematográfica cubana. Presidido por Alfredo Guevara, o Icaic incentivou a produção de documentários, noticiários e filmes de ficção. ${ }^{1}$ Alguns cineastas funda-

* Universidade de Mogi das Cruzes, campus Villa-Lobos. Av. Imperatriz Leopoldina, 550. São Paulo - São Paulo Brasil.silmiskulin@uol.com.br https://orcid.org/0000-0003-4616-9074

${ }^{1}$ Mariana Martins Villaça (2010) refletiu sobre a história do Icaic e analisou as principais polêmicas políticas e estéticas em que a instituição tomou parte entre os anos de 1959 a 1991. Villaça (2010) também mostrou como muitos filmes realizados no Icaic trouxeram elementos inovadores e possibilitaram uma renovação estética no cinema cubano. mentais nesse processo foram Tomás Gutiérrez Alea, Julio García Espinosa, Santiago Álvarez, Humberto Solás, entre outros. A revista Cine Cubano também foi criada com o intuito de ampliar as reflexões culturais e sobre cinema na ilha.

A fundação de Casa de las Américas em 28 de abril de 1959, dirigida por Haydée Santamaría, foi um passo importante na promoção da literatura e da arte cubana e seu intercâmbio com a América Latina. A instituição passou a contar com uma editora, a publicar uma revista bimestral com o mesmo nome e realizar concursos literários anuais, para promover e divulgar a integração cultural latino-americana. ${ }^{2}$

\section{A CRIAÇÃO DE LUNES DE REVO- LUCIÓN}

Entre as novas publicações, destacou-se Lunes de Revolución, que surgiu em 23 de março de 1959, distribuído nas segundas feiras como encarte do jornal Revolución, órgão

${ }^{2}$ Idalia Morejón Arnaiz (2010) analisou, em sua pesquisa de doutorado, a trajetória da revista Casa de las Américas, entre os anos 1960 e 1971 e comparou-a com a revista Mundo Nuevo. 
do Movimento Revolucionário 26 de Julho. Guillermo Cabrera Infante e Pablo Armando Fernández foram respectivamente diretor e subdiretor do suplemento cultural, que tinha a proposta de editar textos culturais, políticos e obras ficcionais.

As proposições de seus editores foram bem explicitadas nos primeiros editoriais da publicação. O primeiro editorial, "Una posición”, definia a proposta do suplemento como uma revista literária, que rechaçava as gerações de intelectuais comprometidas com a ditadura de Batista, propondo ser um veículo para que os intelectuais cubanos atuassem na Revolução. Na concepção de Lunes, a literatura e a arte deviam estar relacionadas com as questões políticas, sociais e econômicas do seu tempo.

O editorial do número 3 situava as posições políticas do suplemento, aproximando-as da ideologia da Revolução. Nesse editorial, $L u$ nes assumiu uma posição política de esquerda, criticando as posições do comunismo na União Soviética, sobretudo, as de sua política cultural, na qual foram adotados os parâmetros do realismo socialista como estética oficial para a literatura e a arte. ${ }^{3}$ Para os editores, a Revolução Cubana não era comunista, e a definição ideológica do suplemento acompanhava as diretrizes do Movimento 26 de Julho: nem comunista, nem anticomunista: ${ }^{4}$

Não somos comunistas. Ninguém: nem a Revolução, nem Revolución, nem Lunes de Revolución. [...] Mas nós, os de Lunes de Revolución, hoje queremos di-

${ }^{3} \mathrm{O}$ realismo socialista, política cultural implementada por Jdanov na União Soviética nos anos 30 e 40, buscou eni⿱ in $^{2}$ quadrar as produções intelectuais dentro de normas patri-

. óticas, otimistas, populares, com uma linguagem que fosse

- acessível ao povo. Conforme analisou criticamente Boris

क Schnaiderman, o realismo socialista foi definido como "a

д representação verídica da realidade em seu desenvolvii mento" (Schnaiderman, 1997, p. 176).

$>{ }^{4}$ O Movimento 26 de Julho, fundado por jovens cubaثี nos, lutava contra a ditadura de Fulgêncio Batista e, no dia 26 de julho de1953, buscou tomar o quartel Moncada $\stackrel{\pi}{ \pm}$ em Santiago de Cuba. Apesar do fracasso da ação, o moif vimento iniciou a guerrilha na Sierra Maestra em 1956. O

Movimento 26 de Julho não era socialista, tinha um pro-

I grama nacionalista e defendia a reforma agrária. Segundo

f Florestan Fernandes, os embates com os Estados Unidos

e a radicalização do processo revolucionário fez com que

houvesse uma "revolução na revolução", e a revolução de

libertação nacional se transformasse em um processo de

डj construção do socialismo (Fernandes, 1979). zer, simplesmente, que não somos comunistas. Para poder dizer também que não somos anticomunistas. Somos, isso sim, intelectuais, artistas, escritores de esquerda - tão de esquerda que as vezes vemos o comunismo passar pelo lado e situar-se à direita em muitas questões de arte e literatura (Editorial..., 1959, p. 3). ${ }^{5}$

O periódico Lunes tornou-se um espaço para a luta ideológica, as contradições políticas e estéticas presentes no período inicial da Revolução. A publicação também manifestou as tensões culturais travadas com José Lezama Lima (Miskulin, 2003, p. 89-94) e com os escritores da extinta revista Orígenes, ${ }^{6}$ como parte do projeto de criar a "verdadeira cultura cubana”. Os questionamentos nas páginas de Lunes em relação aos origenistas significaram uma disputa entre distintos grupos de escritores, já que Orígenes possuía uma concepção de literatura e cultura que se chocava com as perspectivas apontadas em Lunes de Revolución.

Cobrando uma transformação da literatura, voltada mais para o compromisso político da nova realidade cubana, os colaboradores de Lunes rechaçaram a estética origenista, exclusivamente poética, com metáforas e linguagem erudita. As críticas feitas em Lunes aos origenistas eram respaldadas pelo peso que possuía a publicação naquele momento, o que fazia com que as questões estéticas e políticas estivessem totalmente imbricadas. Mas as tensões entre os diversos setores da intelectualidade cubana foram se tornando cada vez mais intensas com o decorrer da Revolução. Diferentes concepções de arte e cultura revolucionária estavam sendo formuladas, buscando sempre responder à nova realidade. Intelectuais que defendiam o realismo socialista chocavam-se com as concepções ecléticas divulgadas em Lunes, como as correntes de vanguarda e escolas literárias e artísticas que propunham experimentações estéticas.

O espaço aberto na publicação para o

${ }^{5}$ As traduções das citações são de minha autoria.

${ }^{6}$ A revista Orígenes, dirigida por José Lezama Lima, circulou entre 1944 e 1956, e foi um grande marco no meio literário e cultural cubano (Barquet, 1990). 
surrealismo, a literatura do absurdo, a arte moderna e abstrata e os beatniks era visto como uma provocação pelos intelectuais ligados ao Partido Socialista Popular (PSP), denominação do Partido Comunista Cubano na época, que acreditavam que tais manifestações culturais não estavam de acordo com as exigências formuladas pelo momento revolucionário (Guillén, 1960). Lunes foi acusado de estrangeirado por esses setores, já que destinava um grande espaço para a divulgação dos intelectuais de outros países (Rodríguez, 1960). Para os editores do suplemento, sua proposta não era incompatível com a perspectiva de se desenvolver a cultura cubana, que deveria responder às questões colocadas pela realidade nacional, sem se fechar às obras de arte e literárias que estavam sendo elaboradas no mundo. ${ }^{7}$

\section{A PROIBIÇÃO DO DOCUMENTÁ- RIO P.M.}

O enfrentamento dos intelectuais comunistas com o grupo de Lunes tornou-se explícito com a proibição do documentário P.M., em maio de 1961, pela comissão revisora do Icaic, responsável pela autorização de exibição dos filmes. O curta, filmado por Sabá Cabrera Infante (irmão de Guillermo Cabrera Infante) e Orlando Jiménez-Leal, foi considerado licencioso, obsceno e difusor de imagens de trabalhadores bêbados (Villaça, 2010). O documentário, cujo nome era a abreviatura de pos$t$-meridiem, mostrava a noite de Havana: restaurantes, bares e seus frequentadores. O Icaic proibiu a exibição pública do documentário, acusando-o de ser contrarrevolucionário, tanto política como esteticamente, e apreendeu a cópia do filme. Alfredo Guevara, presiden-

7 Nesse período, o mundo se encontra em plena guerra fria, com desdobramentos no meio cultural e intelectual, já que as artes e a cultura se transformaram em espacos para propaganda e disputas políticas e ideológicas. A CIA atuou diretamente nessa disputa, financiando revistas, congressos e escritores, e o governo cubano passou a rechaçar muitas obras e produções estrangeiras, sobretudo de exilados cubanos, para fazer frente a guerra fria cultural (Saunders, 2001). te do Icaic, expressou sua opinião sobre P.M: o documentário mostrava o pior dos mundos, a prostituição, o alcoolismo, o tráfico de drogas, o lumpemproletariado, sobretudo negro e mulato, o que era inadmissível e incompatível com sua visão de cinema revolucionário (Guevara apud Chanan, 1985).

O Lunes saiu em defesa de P.M., recolhendo assinaturas de protesto contra sua proibição e apreensão, acusando o Icaic de fazer arte realista socialista, voltada exclusivamente para os alfabetizadores e milicianos. Um dos autores do documentário, Orlando Jiménez-Leal, relacionou a censura de P.M. com uma política burocrática e normativa da Revolução Cubana:

Quando em 1961, meu filme P.M. foi proibido e requisitado sob os auspícios da burocracia de turno, dando origem a uma célebre controvérsia e ao conseguinte escândalo político cultural, nem Sabá Cabrera - coautor do filme - nem eu podíamos imaginar que estávamos sendo sancionados pelo que mais tarde se conheceria como 'conduta imprópria' (Jiménez-Leal apud Almendros; Jiménez-Leal, 1984, p. 9).

Os colaboradores de Lunes haviam reunido inúmeras assinaturas de intelectuais a favor da exibição pública de P.M. O caso foi resolvido com as reuniões na Biblioteca Nacional José Martí, em junho de 1961, em que participaram os principais dirigentes políticos, artistas e intelectuais. Muitos se pronunciaram na defesa do documentário P.M., de Lunes e do jornal Revolución. Entretanto, a censura ao documentário foi ratificada. Revolución e Lunes foram atacados por Alfredo Guevara e outros membros do Icaic, que acusavam o jornal e o suplemento de contrarrevolucionários (Franqui, 1985).

No fechamento do encontro, Fidel Castro realizou o discurso Palavras aos intelectuais e fez um balanço dessas reuniões, ao avaliar que certas pessoas pessimistas revelaram receios de que a Revolução fosse acarretar um cerceamento da liberdade de expressão. Para Fidel Castro, esses setores de intelectuais não seriam genuinamente revolucionários, pois os revolucionários deveriam se preocupar, em primeiro 
lugar, com a garantia de que a Revolução continuasse vitoriosa. Fidel Castro declarou não ter dúvidas de que todos estavam de acordo quanto aos aspectos da liberdade formal de criação, mas que a liberdade de conteúdo era um ponto polêmico, já que alguns intelectuais defendiam uma liberdade absoluta de conteúdo, que não era possível. Fidel estabeleceu, nessas reuniões, a nova política cultural da Revolução: "Isto significa que, dentro da Revolução, tudo; contra a Revolução, nada” (Castro, 1961, p. 11). Normatizava-se a liberdade de expressão dos artistas e escritores cubanos a partir daquele momento, já que Fidel Castro delimitava claramente as fronteiras e as funções dos intelectuais na Revolução Cubana.

Uma grande reestruturação nos organismos culturais foi efetuada. Em agosto de 1961, realizou-se o Primeiro Congresso Nacional de Escritores e Artistas, surgindo a Unión de Escritores y Artistas de Cuba (Uneac), presidida por Nicolás Guillén. Nesse Congresso, o discurso Palavras aos intelectuais foi ratificado e definiu-se que o esforço dos escritores e artistas deveriam ser guiados pela "elaboração de uma nova criação cultural vinculada aos elementos da nacionalidade cubana e às preocupações do povo de Cuba” (Declaración..., 1961, p. 32-33).

A criação da Uneac refletia uma necessi$\rightarrow$ dade de centralização das atividades culturais : Фं de Escritores e Artistas que existiam na União Soviética. O objetivo principal da Uneac seria क ato de censura do governo, que visava a dispersar o grupo de escritores que se reunia ao redor do suplemento. O motivo oficial do fechamento de Lunes foi a falta de papel, mas as razões de sua extinção foram mais profundas e complexas do que a divulgada pelo governo. Os intelectuais que participaram de Lunes eram favoráveis à Revolução, mas propunham, no suplemento, uma política cultural eclética, não dogmática, e o governo não permitiu que um grupo com tais contornos continuasse a ter repercussão e influência na vida cultural cubana. ${ }^{8}$

\section{A EDITORA INDEPENDENTE EL PUENTE}

Diversas editoras surgiram, acompanhando a efervescência cultural da época, e o incentivo às publicações teve um aumento significativo. A editora El Puente nasceu em 1960, dirigida pelo poeta José Mario Rodríguez, e publicava textos de jovens intelectuais, entre eles, os escritores Ana María Simo, Manuel Ballagas, Miguel Barnet, Nancy Morejón, Belkis Cuza Malé, Delfín Prats, Reinaldo Felipe (pseudônimo de Reinaldo Garcia Ramos), Isel Rivero, Georgina Herrera e Mercedes Cortázar. Muitos desses escritores produziam poesia, mas o grupo também publicou contos e reuniu muitos dramaturgos, como Nicolás Dorr, José Ramon Brene, Gerardo Fulleda León e Eugenio Hernández Espinosa. El Puente destacou-se por ser uma editora aberta e polêmica, publi-

${ }^{8} \mathrm{O}$ fechamento do suplemento significou a dispersão dos colaboradores mais frequentes de Lunes. Pablo Armando Fernández foi enviado à Inglaterra em 1962, como conselheiro cultural da embaixada cubana, onde ficou até 1965. Guillermo Cabrera Infante foi, também em 1962, para a Bélgica, quando trabalhou como adido cultural da embaixada cubana. Em 1965, exilou-se na Espanha e depois na Inglaterra. Heberto Padilla viajou em 1965 a Praga e Moscou para ocupar cargos oficiais. Acabou se exilando-se em 1980 nos Estados Unidos, depois de toda a perseguição sofrida pelo "caso Padilla", que explicarei adiante. Virgilio Piñera dirigiu as Ediciones R até 1964 e permaneceu em Cuba, mas morreu no mais completo ostracismo em 1969. Na pesquisa de Mestrado, busquei analisar Lunes de Revolución, sua importância e impacto no mundo cultural cubano (Miskulin, 2003). A pesquisa de mestrado de Barthon Favatto Jr. debruçou-se sobre a trajetória de Guillermo Cabrera Infante e Carlos Franqui, editor do jornal Revolución (Favatto Jr., 2014). 
cando obras literárias inovadoras em sua estética, de escritores jovens, mulheres, negros e homossexuais, dando espaço para as minorias e rompendo certos preconceitos. ${ }^{9}$

A publicação, em 1962, da antologia Novísima Poesía Cubana, organizada por Ana María Simo e Reinaldo Felipe, foi um marco na conformação do grupo, pois não só reuniu todos os poetas que já estavam editando em $E l$ Puente, mas também seu prólogo pode ser tomado como uma verdadeira carta de intenções. Ao se intitularem de novíssimos, os organizadores da antologia definiam o grupo como um movimento renovador de jovens na literatura cubana. Nesse prólogo, reconheciam a importância da revista Orígenes, como parte da importante tradição poética cubana, mas buscavam se distanciar de seu tipo de poesia, que acreditavam ser muito hermética. Sua poesia fazia parte de um outro momento: o grupo buscava uma nova temática e uma outra linguagem. Também criticaram a poesia propagandística, considerada muito afastada do que seria a obra de arte. Distanciavam-se dessas duas vertentes da poesia cubana, já que a consideravam alheias ao homem: "De tudo o que nos antecede devem ter consciência os jovens poetas, se aspiram a uma poesia que reflita o homem no que tem em comum com outros homens e em suas contradições, ao homem que existe, imagina e raciocina" (Felipe; Simo, 1962, p. 13).

Segundo relato recente de José Mario (2000), a antologia recebeu duras críticas por ter publicado dois poetas que, já em 1962, haviam se exilado: Isel Rivero e Mercedes Cortázar. Por outro lado, a partir desse momento, a editora esteve sob a tutela da Uneac, que passou a distribuir seus livros e, posteriormente, a imprimi-los. Dessa maneira, El Puente que era uma editora independente e que tinha total autonomia para decidir quais títulos publicar, foi se transformando em uma editora semiestatal, apesar de sempre lutar para manter sua atitude

${ }^{9}$ Uma antologia de leituras críticas e das poesias publicadas pela editora El Puente foi organizada por Jesús J. Barquet e publicada em 2011 no México (Barquet, 2011). crítica e independente, conforme declarou nos anos 90 a seu editor. A editora planejava publicar uma revista intitulada Resumen Literario El Puente I, para a qual traduziriam o poema Uivo de Allen Ginsberg, sendo que os dois primeiros números estavam quase prontos quando o grupo foi obrigado a se dispersar.

O fechamento de El Puente ocorreu em 1965, quando o Presidente da Uneac Nicolás Guillén, comunicou a José Mario que a instituição não se responsabilizava mais pela editora, já que Fidel Castro havia feito críticas a $E l$ Puente, por ocasião de seu encontro com estudantes e professores de filosofia na Universidade de Havana, entre eles Jesús Díaz (Hasson, 1992). Segundo José Mario (2000), a editora foi acusada de incentivar o poder negro, pois havia muitos negros no grupo, e seus colaboradores foram criticados por suas atividades sexuais. Os escritores comunistas Fayad Jamis e Onelio Jorge Cardoso retiraram da impressão, em 1965, o livro Com temor de Manuel Ballagas, acusando-o de uma temática escabrosa e de corrupção de jovens, já que o livro trabalhava com os problemas sexuais de um adolescente (Mario, 2000). ${ }^{10} \mathrm{~A}$ antologia Segunda Novísima de Poesía foi impressa, mas José Mario não conseguiu retirar os exemplares da gráfica.

\section{A HOMOFOBIA E A REPRESSAO À CONDUTA IMPRÓPRIA}

A perseguição aos homossexuais em Cuba antecedeu o fechamento de Lunes. Em 11 de outubro de 1961, quando a polícia prendeu as prostitutas e os prováveis homossexuais que se encontravam em Havana velha, no bairro Colón, numa noite que ficou conhecida como "la noche de las tres P" (pederastas, prostitutas e proxenetas), marcou-se o início da repressão. Importante colaborador de Lunes e diretor das

${ }^{10} \mathrm{Na}$ pesquisa de Doutorado, analisei o papel das edições El Puente, seu fechamento, as perseguições e exílio dos principais escritores do grupo, além de pesquisar também o surgimento da publicação El Caimán Barbudo e a institucionalização da política cultural ao longo dos anos 60 e 70 (Miskulin, 2009a). 
Ediciones $R$ (editora que pertencia ao grupo), Virgilio Piñera foi preso no dia seguinte, quando saía de sua casa na praia, bem distante do centro de Havana e foi libertado pouco depois, devido à intervenção de Carlos Franqui, diretor de Revolución. Alguns anos depois, a política de repressão aos homossexuais e a todos aqueles que tivessem uma "conduta imprópria" foi implementada com o surgimento de campos de trabalhos forçados, as Umaps, como veremos mais adiante.

Ainda nos anos 1960, José Mario (1969) relatou, na revista Mundo Nuevo, como ele e Manuel Ballagas foram presos durante a estadia de Allen Ginsberg na ilha, mas foram soltos graças à sua intervenção junto à Casa de las Américas e à Uneac. Ginsberg esteve em Cuba em 1965, como membro do júri de poesia do Concurso Casa de las Américas. Acabou deportado para Praga, por ter feito "declarações escandalosas”, ao manifestar seu desejo por Che Guevara, propagar boatos de que Raúl Castro era homossexual e ao questionar a proibição do consumo de maconha. Em entrevista posterior ao episódio, Ginsberg relatou sua expulsão e a perseguição aos escritores de El Puente, que passaram a ser impedidos de publicar, entre outros elementos, por serem homossexuais:

Um bando de garotos de um clube de poesia que $\underset{7}{2} \quad$ eu conhecia muito bem, El Puente, estava na mira nove meses na Unidade Militar de Ayuda a la Producción (Umap) e esteve posteriormente na prisão militar La Cabaña, até que conseguiu se exilar em 1968 (Mario, 2000). Ana María Simo foi presa e internada em hospital psiquiátrico, sofrendo todo tipo de perseguições entre 1965 a 1967, quando conseguiu exilar-se na França (Almendros; Jimenez-Leal, 1984). Anos depois, nos anos 70, René Ariza e Manuel Ballagas também foram condenados a muitos anos de prisão por "diversionismo ideológico".

O governo pretendeu controlar a conduta sexual pública dos cubanos, visando principalmente aos homossexuais e, entre eles, os intelectuais. Uma política de perseguição individualizada transformou-se, em 1964, numa política massiva de perseguição, com buscas e internamentos de homossexuais (reais ou presumidos) nas Umaps, em Camaguey, que funcionavam como campos de trabalhos forçados para os “desviados" ideológicos ou sexuais. Nas Umaps, também eram presos todos os dissidentes, os hippies, os jovens que queriam sair do país, os religiosos (seminaristas católicos e ministros protestantes de igrejas do interior), os estudantes "depurados" das universidades, os intelectuais, os camponeses jovens que se recusavam a integrar-se às cooperativas e os proprietários de pequenos negócios urbanos. Quando jovem, o músico Pablo Milanés foi enviado às Umaps e, em 2015, deu seu depoimento a El País:

Estivemos ali, entre 1965 e finais de 1967, eu e mais de 40 mil outras pessoas, em campos de concentração isolados na província de Camaguey, realizando trabalhos forçados desde as cinco de madrugada até o anoitecer, sem nenhuma justificativa ou explicações, e muito menos o perdão que estou esperando que o Governo cubano peça. Eu tinha 23 anos, fugi de meu acampamento - e me seguiram mais 280 companheiros que estavam presos no mesmo território que eu - e fui a Havana para denunciar a injustiça que estavam cometendo. O resultado foi que me enviaram dois meses à prisão de La Cabaña, e depois fui transferido para um acampamento de castigo pior que as Umap, onde permaneci até que estas unidades fossem dissolvidas devido à pressão da opinião internacional (Milanés apud Chomsky, 2015, p. 151). 
As pressões internacionais foram significativas e colaboraram para que o governo decidisse fechar os campos em 1966 (Bejel, 2001; Quiroga, 2000).

\section{O SURGIMENTO DO SUPLEMEN- TO EL CAIMÁN BARBUDO}

O vazio representado pelo fechamento de Lunes de Revolución e El Puente procurou ser preenchido pelo novo suplemento literário El Caimán Barbudo, surgido em maio de 1966 como encarte mensal do jornal Juventud Rebelde. ${ }^{11}$ Dirigido pelo escritor e professor de filosofia, Jesús Díaz, El Caimán Barbudo teve como chefe de redação Guillermo Rodríguez Rivera, Juan Ayús como artista gráfico e, como ilustrador, José Luis Posada. Colaboravam no suplemento os escritores Norberto Fuentes, Luis Rogelio Nogueras, Raúl Riveo e Vítor Casaus, entre outros.

Em seu primeiro número, os editores apresentaram as diretrizes da publicação e explicitaram suas intenções de elaborar uma publicação cultural ampla, abertamente comprometida com a Revolução:

El Caimán Barbudo faz-se presente. Obra dos jovens revolucionários, estará, como eles, comprometida só com a Revolução, com seu Partido, que é igual a estar comprometida com a verdade e com a arte. A arte verdadeira não foi nem poderá ser jamais contrarrevolucionaria. [...] Cremos com Fidel, que deve ser preocupação fundamental da Revolução o desenvolvimento espiritual do homem novo. Órgão dos jovens, seja este um chamado à colaboração e à crítica. Sabemos que a arte não está divorciada da vida; nossa publicação tratará de literatura e política; de artes plásticas e de filosofia (Apresentação..., 1966, p. 1-2).

El Caimán Barbudo publicou também, nesse primeiro número, o manifesto Nos pronunciamos, no qual escritores e jornalistas

${ }^{11} \mathrm{O}$ diário Juventud Rebelde, órgão de imprensa da juventude do Partido Comunista Cubano, surgiu em outubro de 1965, ano em que se fundou o PCC. El Caimán Barbudo é publicado desde 1966 até os dias de hoje, atualmente editada como revista. defendiam a poesia criativa, livre, de versos irregulares, por eles denominada "nova poesia cubana" e, ao mesmo tempo, manifestavam seu apoio à Revolução. ${ }^{12} \mathrm{O}$ manifesto repercutiu entre a intelectualidade, já que criticava tanto a concepção de poesia pura, como a de poesia panfletária. ${ }^{13}$

As tensões entre os escritores que se agruparam em torno de El Puente e de El Caimán Barbudo foram explícitas. No mesmo ano em que surgiu o suplemento, Jesús Díaz foi convidado a participar de reportagens na revista La Gaceta de Cuba, para definir a geração de escritores pós-Revolução. Em seu artigo, Jesús Díaz criticou duramente os escritores de El Puente como a parte mais devassa e libertina da jovem geração, atacando tanto sua qualidade artística como suas posições políticas: "Sua primeira manifestação de grupo foi o editorial El Puente, marcada pela fração mais dissoluta e negativa da geração atual. Foi um fenômeno errado política e esteticamente. Há que ressaltar este último aspecto: no geral, eram maus artistas" (Díaz, 1966, p. 9).

Apesar do direito de resposta a Ana María Simo, que escreveu um artigo defendendo a editora El Puente, surgida como necessidade de publicação de jovens escritores que tinham uma estética revolucionária, sua posição foi novamente criticada por outro artigo de Jesús Díaz, editado no número consecutivo de $L a$ Gaceta de Cuba. Essa polêmica foi reveladora de tensões entre dois grupos de escritores, um patrocinado pela União da Juventude Comunista (UJC) e outro independente, que foram acolhidos de maneira diferenciada pela política cultural oficial.

Entretanto os colaboradores de El Caimán Barbudo não conseguiram ficar por muito tempo na direção do suplemento. Os escrito-

12 Posteriormente, os críticos literários chamaram essa poesia de poesía conversacional ou prosaísta (Rodríguez Rivera, 2000).

13 O manifesto foi assinado por Orlando Alomá, Sigifredo Alvarez Conesa, Iván Gerardo Campanioni, Víctor Casaus, Félix Contreras, Froilán Escobar, Félix Guerra, Rolén Hernández, Luis Rogelio Nogueras, Helio Orovio, Guillermo Rodríguez Rivera e José Yanes (Nos pronunciamos, 1966, p. 11). 
res Heberto Padilla e Lisandro Otero, esse último vice-presidente do Consejo Nacional de Cultura, travaram uma polêmica nas páginas de El Caimán Barbudo a respeito do prêmio Biblioteca Breve, recebido em 1967 por Guillermo Cabrera Infante, por seu romance Tres Tristes Tigres. Lisandro Otero também concorreu ao prêmio com Pasión de Urbino. Padilla publicou um artigo no suplemento defendendo o livro de Cabrera Infante e criticando o de Otero. Apesar de os editores manifestarem sua posição contrária às de Padilla, o fato de terem publicado o artigo que mencionava um escritor exilado foi motivo de grande descontentamento na União da Juventude Comunista. A substituição da junta editorial do suplemento e a remoção de Jesús Díaz da direção de El Caimán Barbudo foram efetivadas em janeiro de 1968, como consequência dessa polêmica. ${ }^{14} \mathrm{~A}$ publicação continuou sendo editada ao longo dos anos 70 por outras equipes de escritores diretamente vinculadas à UJC.

\section{O CASO PADILLA E OS ANOS CINZA}

Esse episódio em El Caimán Barbudo foi apenas o início dos problemas do escritor o Padilla. O caso Padilla foi o evento mais sig: nificativo do fechamento cultural e marcou o đ fim da "lua de mel" entre o governo cubano e a intelectualidade de esquerda internacio$\infty$

¿ 14 Jesús Díaz, posteriormente, fez parte do conselho de * redação da revista Pensamiento crítico, do Departamento

- de Filosofia da Universidade de Havana, que também foi

$>$ fechada em 1971, juntamente com o próprio Departamen-

oิ to, acusados de “diversionismo ideológico”. Díaz passou a

Trabalhar no Icaic, escreveu roteiros e dirigiu dois filmes,

mas, nos anos 90, exilou-se em Madri, onde fundou, em

๘ 1996, a revista Encuentro de la cultura cubana (Martínez Perez, 2006). próprio Heberto Padilla (1989, 1998) e do escritor chileno Jorge Edwards (1991), na época embaixador do Chile em Cuba. Há também a importante cronologia elaborada por Teresa Cristófani Barreto (2000). escritores Manuel Díaz Martínez, César López, Norberto Fuentes, Pablo Armando Fernández, Antón Arrufat, Lezama Lima e Virgilio Piñera. Sua autocrítica foi lida publicamente no salão de atos da Uneac, no dia 17 de abril de 1971, em sessão presidida por José Antonio Portuondo, quando Padilla se viu obrigado a ampliar a sua confissão diante de muitos agentes de segurança do Estado, que filmaram o episódio.

O caso ganhou repercussão internacional. Escritores de esquerda, que até então haviam defendido a Revolução, como Jean-Paul Sartre, Simone de Beauvoir, Italo Calvino, Marguerite Duras, Juan Goytisolo, Alberto Moravia, Octavio Paz, Hans Magnus Enzensberger, André Pieyre de Mandiargues, Alain Jouffroy, Joyce Mansour, Julio Cortázar, Carlos Fuentes, García Márquez, Vargas Llosa, entre outros, publicaram uma carta no jornal Le Monde, em 9 de abril de 1971, questionando a prisão de Padilla. Uma outra carta dirigida a Fidel Castro foi publicada em 21 de maio no jornal Madrid e também em Paris, em que sessenta intelectuais, entre eles Nathalie Sarroute, Susan Sontag, Carlos Franqui, Pasolini e Resnais protestaram enfaticamente diante da confissão pública de Padilla, que se redimia de crimes políticos que tinham sido forjados. ${ }^{16}$

Considerado um marco na política cultural oficial da Revolução, o Primeiro Congresso Nacional de Educação e Cultura realizou-se entre 23 a 30 de abril de 1971. Em seu discurso de encerramento do Congresso, Fidel Castro, dez anos depois de Palabras a los intelectuales, continuava a definir padrões morais, ideológicos e sexuais que deveriam guiar os intelectuais e educadores. Suas obras deveriam ser "uma arma da Revolução" e seriam "úteis para o povo, para a libertação do homem”. A produção cultural estaria, a partir desse momento, subordinada às necessidades da educação. Fidel também teceu críticas aos intelectuais es-

${ }^{16}$ A repercussão internacional do caso Padilla foi imensa no meio intelectual (Costa, 2013; Verdès-Leroux, 1989). Na pesquisa de Pós-Doutorado, analisei como as revistas mexicanas Plural e Vuelta, dirigidas por Octavio Paz, repercutiram essa polêmica em suas páginas (Miskulin, 2010). 
trangeiros que publicaram cartas na imprensa internacional, condenando o caso Padilla.

As resoluções desse Congresso intensificaram a repressão aos intelectuais homossexuais, impedindo-os de exercer qualquer função educacional ou cultural em Cuba:

Não se pode permitir que, por seus 'méritos artísticos', reconhecidos homossexuais influenciem a formação de nossa juventude. Como consequência, é necessário analisar como se deverá encarar a presença de homossexuais nos diversos organismos da frente cultural. Sugeriu-se o estudo de medidas que permitam o encaminhamento para outros organismos daqueles que, sendo homossexuais, não devam ter participação direta na formação de nossa juventude a partir de atividades artísticas ou culturais (Resoluções..., 1980, p. 29).

O endurecimento no campo cultural fez com que os anos 70 ficassem conhecidos como a "década gris da cultura cubana" (Cancio Isla apud Barquet, 1998b, p. 72). O crítico literário Ambrosio Fornet, bastante afinado com a linha oficial governamental, reconheceu que 1971 marcou o início do "quinquenio gris" (Fornet apud Espinosa, 1992, p. 103). Há ainda interpretações mais críticas, como a de Desiderio Navarro, que apontam pelo menos quinze anos, de 1968 a 1983, como o período de autoritarismo e dogmatismo cultural (Navarro, 2002).

A "parametrización de la cultura cubana" significou o estabelecimento de parâmetros ideológicos e morais que deveriam direcionar a conduta dos intelectuais. $\mathrm{O}$ diretor do Consejo Nacional de Cultura, Luis Pavón Tamayo, passou a impulsionar uma "campanha de saneamento", em que muitos intelectuais e artistas foram expulsos de seus postos de trabalho, acusados de terem "conduta imprópria". A partir desse momento, os intelectuais teriam de demonstrar "combatividade revolucionária”, ou seja, participar como um militante das tarefas da Revolução (Barquet, 1998b, p. 71).

As obras artísticas e literárias deveriam escolher temas épicos e triunfalistas, demonstrando uma orientação política rígida. Valorizavam-se obras didáticas, que "refletissem o momento de construção do socialismo em Cuba”. A crítica literária Mirta Aguirre (1987) defendeu o "realismo socialista cubano", que, para ela, se aproximava dos cânones do modelo soviético. O realismo socialista foi incentivado principalmente pelos intelectuais que aderiram ao PCC, ou ainda por aqueles que já eram militantes comunistas antes do triunfo da Revolução. O cientista político Rafael Hernández reconheceu que houve uma enorme aproximação do modelo soviético e que as imitações do "socialismo real" soviético afetaram o sistema, a cultura e o pensamento na ilha (Hernández, 1999, p. 62).

O êxodo de Mariel, no ano de 1980, com o exílio de muitos intelectuais (entre eles Manuel Ballagas e Reinaldo García Ramos, que publicaram em El Puente) e homossexuais, foi um novo marco para a história cubana. ${ }^{17} \mathrm{Nessa}$ ocasião, dez mil pessoas se refugiaram na embaixada do Peru, pedindo asilo político, e cerca de 120 mil pessoas deixaram Cuba pelo porto de Mariel, emigrando para os Estados Unidos, chegando a Key West entre abril e setembro daquele ano (Barquet, 1998a; Marques, 2012).

A realização do Segundo Congresso do Partido Comunista Cubano, em 1980, foi outro marco importante, sinalizando uma série de mudanças. Muitos intelectuais que tinham visto suas obras perseguidas foram, pouco a pouco, ganhando espaço novamente. Iniciou-se, lentamente, uma retomada das experimentações da década de 1960 e mudanças no mundo cultural vêm se desenvolvendo desde meados dos 1980. Nesse período, certos escritores e artistas começaram a contestar a repressão que alguns funcionários praticavam, buscando corrigir os erros da "parametrización". O governo cubano procurou incentivar políticas culturais mais abertas, priorizando o trabalho de intelectuais ao de funcionários do partido, incentivando o surgimento de novas criações

${ }^{17}$ A autobiografia de Reinaldo Arenas é um importante registro das perseguições sofridas por um intelectual homossexual, que saiu de Cuba com o êxodo de Mariel (Arenas, 1995; Miskulin, 2009b). Ver também o filme Antes do anoitecer, de Julian Schnabel, produzido nos Estados Unidos, em 2000 , sobre a vida de Arenas. 
individuais e coletivas, promovendo uma descentralização com a criação de novas instituições, como as Casas de Cultura.

A partir de 1990, com o fim da União Soviética e do bloco do Leste Europeu, Cuba passou a vivenciar um novo período, denominado de "período especial em tempos de paz", marcado por grandes crises, dificuldades econômicas e materiais para a maioria da população (López Segrera, 2012), o que impôs novos desafios aos intelectuais e ao desenvolvimento da cultura, indo desde os limites da liberdade de criação e expressão, do acesso à internet e à manutenção das conquistas sociais da Revolução Cubana.

\section{CONSIDERAÇÕES FINAIS}

Os teóricos que analisaram as políticas culturais em Cuba enfatizaram a efervescência dos anos 1960 como um momento de enorme produção intelectual, enquanto que a década de 1970, sobretudo após as deliberações do Congresso de 1971, foi vista como um período de endurecimento, marcado por grande repressão e pelo estabelecimento de normas rígidas, que cercearam a conduta dos intelectuais e a elaboração de suas obras.

Entretanto observamos que, já na décao da de 1960, ocorreram diversos conflitos entre 定 certos grupos de intelectuais e o governo, que Фं acarretaram a censura de certos filmes, obras ou publicações. O caso do fechamento de $\mathrm{Lu}$ cultural muito anterior ao ano de 1971.

A definição da política cultural oficial, no processo revolucionário, foi elaborada fun- damentalmente pelos dirigentes políticos, que determinaram o espaço dos intelectuais na Revolução Cubana no decorrer das últimas cinco décadas. Apesar das mudanças no campo cultural que vêm se desenvolvendo desde meados dos anos 1980, elas não são acompanhadas por amplas reformas políticas, o que impede que a liberdade de criação e expressão em Cuba seja plena.

A Revolução Cubana trouxe muitos benefícios e conquistas para a maioria da população, ao diminuir as desigualdades sociais que existiam na ilha, acabar com o analfabetismo e dar acesso à educação e à saúde para a maioria da população. Mas, infelizmente, não conseguiu garantir os direitos civis e a liberdade plena dos indivíduos no âmbito da esfera privada ou pública. A censura, as diretrizes, normas e parâmetros oficiais estão e estiveram presentes. $\mathrm{O}$ acesso restrito à informação, à imprensa estrangeira e à internet impede maior liberdade no trabalho intelectual na ilha. A ampla liberdade de criação, expressão e de associação política segue sendo uma questão não resolvida pela política oficial em Cuba.

Recebido para publicação em 04 de maio de 2019 Aceito em 12 de novembro de 2019

\section{REFERÊNCIAS}

AGUIRRE, M. "Realismo, realismo socialista y la posición cubana”. In: ESCALONA, J. F. Estética selección de lecturas. Havana: Editorial Pueblo y Educación, 1987.

ALMENDROS, N.; JIMÉNEZ-LEAL, O. Conducta impropia. Madri: Playor, 1984.

APRESENTAÇÃO. El Caimán Barbudo, Havana, n. 1, p. 1-2, abr. 1966.

ARENAS, R. Antes que anoiteça. Trad. Irène Cubrie. Rio de Janeiro: Record, 1995.

BARQUET, J. “La generación de Mariel”. Encuentro de la cultura cubana, Madri, n. 8-9, p. 110-125, primavera-verão 1998a.

BARQUET, J. "El teatro cubano en la encrucijada sociopolítica (1959-1990)". La palabra y el hombre, n. 108, p. 63-80, out./dez. 1998b.

BARQUET, J. El grupo orígenes y la eticidad cubana: recuento de un proceso. [S. l.]: Tulane University, 1990.

BARQUET, J. Ediciones el puente en La Habana de los años 60: lecturas críticas y libros de poesía. México: Ediciones del Azar, 2011. 
BARRETO, T. C. A libélula, a pitonisa: revolução, homossexualismo e literatura em Virgilio Piñera. São Paulo: Iluminuras: Fapesp, 1996.

BARRETO, T. C.; GIANERA, P.; SAMOILOVICH, D. "Virgilio Piñera. Cronologia". Trad. de Teresa Cristófani Barreto. Revista Usp, São Paulo, n. 45, p. 151-154, mar. maio 2000 .

BEJEL, E. Gay Cuban Nation. Chicago: Londres: The University of Chicago Press, 2001.

CABRERA INFANTE, G. Mea Cuba. Trad. Josely Vianna Baptista. São Paulo: Companhia das Letras, 1996.

CASTRO, F. Palabras a los intelectuales. Havana: Ediciones del Consejo Nacional de Cultura, 1961. p. 11.

CHANAN, M. The Cuban image: cinema and cultural politics in Cuba. Bloomington: Indiana University Press, 1985.

CHOMSKY, A. História da Revolução Cubana. Trad. de Guilherme Miranda. São Paulo: Veneta, 2015.

COSTA, A. V. Intelectuais, política e literatura na América Latina. São Paulo: Alameda: Fapesp, 2013.

"DECLARACIÓN final del Primer Congreso Nacional de Escritores y Artistas de Cuba". Lunes de revolución, Havana, n. 120, p. 32-33, ago. 1961.

DÍAZ, J. "Encuesta generacional”. La Gaceta de Cuba, Havana, n. 50, p. 9, abr./maio 1966.

DÍAZ, J. "El fin de otra ilusión. A propósito de la quiebra de El Caimán Barbudo y la clausura de Pensamiento crítico". Encuentro de la cultura cubana, Madri, n. 16-17, p. 106-119, 2000

EDITORIAL "una posición: haciendo lo que es necesario hacer". Lunes de revolución, Havana, n. 3, p. 3, 1959.

EDWARDS, J. Persona non grata. Barcelona: Tusquets Editores, 1991

ESPINOSA, C. "Uma dramaturgia escindida: cronología". In: TEATRO cubano contemporáneo: antología. Madri Fundo de Cultura Económica, 1992. p. 13- 127.

FAVATTO JR., B. Entre o doce e o amargo: memorias de exilados cubanos. São Paulo: Alameda: Fapesp, 2014.

FELIPE, R.; SIMO, A. M. (Org.). Novísima poesía cubana. Havana: Ediciones El Puente, 1962.

FERNANDES, F. Da guerrilha ao socialismo: a Revolução cubana. São Paulo: T. A. Queiroz, 1979.

FRANQUI, C. Retrato de família com Fidel. Trad. de Fábio Fernandes da Silva. Rio de Janeiro: Record, 1985.

GINSBERG, A. "Allen Young entrevista Allen Ginsberg". In: LEYLAND, W. (Org.). Sexualidade \& criação literária: as entrevistas do Gay sunshine. Trad. de Raul Sá Barbosa. Rio de Janeiro: Civilização Brasileira, 1980.

GUILLÉN, N. "Lunes de Revolución”. Hoy, Havana, mar. 1960.

HASSON, L. "Le discours sur la culture cubaine dans Mundo Nuevo (1966-1971)". América: Cahiers du CRICCAL, Paris, n. 9-10, p. 65-74, 1992.

HERNÁNDEZ, R. Mirar a Cuba: ensayos sobre cultura y sociedad civil. Havana: Editorial Letras Cubanas, 1999

LÓPEZ SEGRERA, F. A Revolução cubana: propostas, cenários e alternativas. Trad. de Mário Luiz Neves de Azevedo e Gilda Teresa Contreras López. Maringá: Eduem, 2012.

MARIO, J. "Allen Ginsberg en La Habana". Mundo nuevo, Paris, p. 48-54, abr. 1969.

MARIO, J. "La verídica história de Ediciones El Puente, La Habana, 1961-1965”. Revista hispano cubana, Madri, n. 6 , p. 89-100, 2000.

MARQUES, R. L. A condicão Mariel: memórias subterrâneas da Revolução Cubana. Goiânia: Edufma: PUC Goiás, 2012.

MARTÍNEZ PÉREZ, L. Los hijos de Saturno: intelectuales y Revolución en Cuba. México: Flacso: Miguel Ángel Porrúa, 2006.

MISKULIN, S. C. Cultura ilhada: imprensa e Revolução cubana. São Paulo: Xamã: Fapesp, 2003.

MISKULIN, S. C. Os intelectuais cubanos e a política cultural da Revolução. São Paulo: Alameda: Fapesp, 2009a.

MISKULIN, S. C. "Outro olhar sobre a Revolução Cubana: a trajetória e obra de Reinaldo Arenas na revista Vuelta”. Revista brasileira do Caribe: Revista do Centro de Estudos do Caribe no Brasil, Brasília, v. 10, n. 19, p. 191-208, jul./dez. 2009b.

MISKULIN, S. C. "La Revolución Cubana y el caso Padilla en las revistas Plural y Vuelta". Estudios: Revista del Centro de Estudios Avanzados da Universidad Nacional de Córdoba, Córdoba, n. 23-24, p. 159-171, jan./dez. 2010.

MOREJÓN ARNAIZ, I. Política y polémica en América Latina: Las revistas Casa de las Américas y Mundo Nuevo. México: Educación y Cultura, 2010.

“NOS pronunciamos”. El Caimán Barbudo, Havana, n. 1, p. 11, maio 1966

NAVARRO, D. "In medias res publicas. Sobre los intelectuales y la crítica social en la esfera pública cubana”. In: HERNÁNDEZ, R.; ROJAS, R. (Org.). Ensayo cubano del siglo XX. México: Fondo de Cultura Económica, 2002. p. 689- 707.

PADILLA, H. La mala memoria. Barcelona: Plaza \& Janes, 1989.

PADILLA, H. Fuera del juego. Miami: Ediciones Universal, 1998.

QUIROGA, J. Tropics of desire Interventions from Queer Latino America. Nova York: Londres: New York University Press, 2000

RESOLUCÕES do Primeiro Congresso Nacional de Educação e Cultura. São Paulo: Livramento, 1980.

RODRÍGUEZ, C. R. "¿Porque me gusta y no me gusta Lunes?”. Lunes de Revolución, n. 52, Havana, p. 4, mar. 1960

RODRÍGUEZ RIVERA, G. "La poesía de Luis Rogelio Nogueras". Encuentro de la Cultura Cubana, Madri, n. 18, p. 223-233, 2000 .

ROJAS, R. "Apuntes para una historia intelectual". In: NARANJO OROVIO, C. (Org.). Historia de Cuba. Madri: CSIC: Ediciones Doce Calles, 2009. p. 393-416.

ROJAS, R. "Anatomía del entusiasmo: cultura y revolución en Cuba". In: ALTAMIRANO, C. (Org.). Historia de los intelectuales en America Latina. Buenos Aires: Madri: Katz Editores, 2010. p. 45-61.

SAUNDERS, F. S. La CIA y la guerra fría cultural. Madri: Editorial Debate, 2001

SCHNAIDERMAN, B. Os escombros e o mito: a cultura e o fim da União Soviética. São Paulo: Companhia das Letras, 1997.

VERDÈS-LEROUX, J. La lune et le caudillo: le rêve des intellectuels et le régime cubain (1959-1971). Paris: Gallimard, 1989.

VILLACA, M. M. Polifonia tropical: experimentalismo e engajamento na música popular (Brasil e Cuba, 19671972). São Paulo: Humanitas, 2004. (Série Teses/ História Social USP).

VILLACA, M. M. Cinema cubano: revolução e política cultural. São Paulo: Alameda: Fapesp, 2010. 


\section{CULTURAL POLICY IN THE CUBAN REVOLUTION: intellectual disputes in the 1960s and 1970s}

\section{Sílvia Cezar Miskulin}

The Cuban Revolution promoted great transformations in the society of the island. New publications, cultural institutions and artistic manifestations accompanied the political and cultural effervescence throughout the 1960s. This research analyzed the cultural supplement Lunes de Revolución, the El Puente publishing house and the El Caimán Barbudo cultural supplement, with the aim of showing the emergence of new publications and cultural manifestations in Cuba after the triumph of the Revolution. However, the emergence of a cultural policy has led to the normalization and control of cultural productions by the Cuban government since the 1960s, and especially after 1971, when the closing and hardening of the Cuban cultural milieu became more pronounced.

KeY wORDS: Cuba. Revolution. Culture. History. Intellectual.

\section{LA POLITIQUE CULTURELLE DANS LA REVOLUTION CUBAINE: controverses intellectuelles dans les annees 1960 et 1970}

\author{
Sílvia Cezar Miskulin
}

La révolution cubaine a promu de grandes transformations dans la société de l'île. De nouvelles publications, des institutions culturelles et des manifestations artistiques ont accompagné l'effervescence politique et culturelle tout au long des années 1960.Cette recherche a analysé le supplément culturel Lunes de Revolución, la maison d'édition El Puente et le supplément culturel El Caimán Barbudo, dans le but de montrer l'émergence de nouvelles publications et manifestations culturelles à Cuba après le triomphe de la Révolution. Cependant, l'émergence d'une politique culturelle a conduit à la normalisation et au contrôle des productions culturelles par le gouvernement cubain depuis les années 1960, et encore plus après 1971, lorsque la fermeture et l'endurcissement du milieu culturel cubain se sont accentués.

Mots CLÉs: Cuba. Révolution. Culture. Histoire. Intellectuel. Paulo: Xamã: Fapesp, 2003, entre outros livros e artigos. 